\title{
The International Centre for Settlement of Investment Disputes
}

\author{
Funnekotter and Others v. Republic of Zimbabwe, Case No. Arb/05/6 - \\ a test case for commercial farmers in Zimbabwe or: how ICSID can fill the \\ gap in the protection of human rights violated by a lawless state like \\ Zimbabwe
}

\section{By Cornelia Glinz, Heidelberg*}

\section{A. Introduction}

The case Funnekotter and Others versus the Republic of Zimbabwe, which was decided on the $22^{\text {nd }}$ April 2009 by an ICSID Tribunal deals with the claims of 13 Dutch farmers who were displaced from their farmland in Zimbabwe without compensation during Zimbabwe's notorious land reform programme. ${ }^{1}$ In question was the alleged breach of the Bilateral Investment Treaty concluded between the Netherlands and Zimbabwe ${ }^{2}$. The Tribunal declared the Republic of Zimbabwe in breach of international law and bilateral treaty protections. It ordered Zimbabwe to pay damages of 8 Million Euros plus interest, amounting to approximately 16 Million Euros in total. It can be considered a land mark decision, since it is a major success for victims of land seizures in Zimbabwe. Moreover, the award is the first one that gives meaningful financial relief to the commercial farmers for their losses. However, it was not the first time that farmers who lost their land in similar ways in Zimbabwe sought redress before an international adjudicator. Already in 2007 a case was brought before the Tribunal of the South African Development Community (SADC), the so called SADC Tribunal. In this case, known as the Campbell-case, a judgment was delivered on the $28^{\text {th }}$ November $2008 .^{3}$ There, the regional Tribunal dealt with the expropriations of 79 farms by the Republic of Zimbabwe. In its judgment, it set an example by stating that

* Cornelia Glinz, Ass. iur., Research Fellow at the Max Planck Institute for Comparative Public Law and International Law, Heidelberg. E-mail: cglinz@mpil.de [Hereinafter Funnekotter]; the case is printed in: International Legal Materials, 48 (2009), p. 764 ff., with a brief annotation by Ben Love, p. $760 \mathrm{ff}$.

2 Agreement on encouragement and reciprocal protection of investments between the Republic of Zimbabwe and the Kingdom of the Netherlands, 11.12.1996 (signed), 01.05.1998 (entered into force).

Mike Campbell (Pvt) Ltd et al v. The Republic of Zimbabwe, SADC (T) Case No. 02/2007. On this judgment, see Oliver C. Ruppel, The Southern African Development Community (SADC) and its Tribunal: Reflexions on a Regional Economic Communities' Potential Impact on Human Rights Protection, Verfassung und Recht in Übersee, 42 (2009), p. 182 ff.; Gino J. Naldi, Mike Campbell (Pvt) Ltd et al v The Republic of Zimbabwe: Zimbabwe's Land Reform Programme Held in Breach of the SADC Treaty, Journal of African Law 53 (2009), p. 305 ff. The judgment is printed in: International legal materials 48 (2009), p. $534 \mathrm{ff}$. 
the land reform programme was in breach of the SADC Treaty ${ }^{4}$ and of the commitment of its Member States to human rights and the rule of law. However the judgment proved to be meaningless to the Claimants in practice, since Zimbabwe refrained from fulfilling its obligations under the judgment. Thus, the two cases provide an interesting comparison of how, firstly, a regional Tribunal and an international arbitration Tribunal deal with human rights violations and secondly, of the enforcement mechanisms of the two regimes.

\section{B. Background}

First of all, to give a background to the case, it has to be seen in the context of the history and legal development of Zimbabwe's land reform programme. ${ }^{5}$ In 1992, the Zimbabwean government passed the Land Acquisition Act, which authorised compulsory acquisition of land for agricultural resettlement purposes. Under its Article 5, the first step for such an acquisition was the issuance of a preliminary notice which deprived the owner of the right to dispose of the land. In a second step, an acquisition of land order could be issued according to Article 8. Although a provision of the Act provided for the payment of fair compensation, in practice, no or at least no adequate compensation was granted. In 2000, the government then proposed a new Constitution which provided for the acquisition of land without compensation. This proposal was defeated in a referendum in February 2000. That defeat immediately resulted in violent invasions of commercial farms, led by so called war veterans who fought in the 1970s War of Liberation. They were encouraged and supported by the Zimbabwean government and the police did not intervene. Only two months after the defeat of the proposed Constitution, a constitutional amendment was finally adopted which abolished the duty to pay compensation. By contrast, expropriated farmers were referred to the United Kingdom as former colonial power to request compensation from them. ${ }^{6}$ An amendment of the Land Acquisition Act followed which stated that "compensation shall only be payable for any improvements on or to the land" (Section 29C). Subsequently, an accelerated Land Reform and Resettlement Plan, known as "Fast Track Programme" was started. To protect the illegal occupiers of the farms, the Parliament of Zimbabwe enacted the Rural Land Occupiers (Protection from Eviction) Act in June 2001. Under this Act, occupiers of rural land were protected against eviction. Finally, in 2005, the Zimbabwean Constitution was again amended. Through this amendment the remaining safeguards contained in the Land Acquisition Act were revoked and vast areas of agricultural land were directly transferred to the state. ${ }^{7}$

The Treaty of the Southern African Development Community, 32 I.L.M. 120 (1993), 17.08.1992 (signed), 13.09.1993 (entered into force), amended by SADC Treaty-amendment (2001), 14 Member States (checked 28.05.2010).

Funnekotter, para $21 \mathrm{ff}$.

6 Section 16A (1) (c), Amendment No. 2, 2000.

7 Section 16B, Amendment No. 17, 2005. 


\section{The award \\ I. The facts}

First steps in the case were taken in 2003, when 13 Dutch farmers turned to ICSID and requested arbitration against the Republic of Zimbabwe. The request for arbitration was registered by the Center in April 2005. ${ }^{8}$ After the Parties failed to agree on the composition of the Tribunal, in 2006 the former President of the ICJ Gilbert Guillaume was appointed as the presiding arbitrator. ${ }^{9}$ An oral hearing of the Parties was held over three days in Paris in October 2007. The thirteen Claimants, all of them of Dutch nationality, had directly or indirectly owned large commercial farms in Zimbabwe. All of them have been dispossessed of their farmland sometime between 2001 and 2003. Most of them have been forcibly evicted through violent land invasions by war veterans. Additionally, in the majority of cases, the Zimbabwean authorities also issued orders under Section 8 of the Land Acquisition Act to deprive the Claimants of their property. However, none of them received any compensation. The Commercial Farmers' Union had challenged the occupation of the farms before the Zimbabwean Courts. In 2000 the Supreme Court found that acquisition of farms without compensation under the Fast Track Programme was unconstitutional and the farm invasions were unlawful. In the following year, the composition of the Supreme Court was changed. In a subsequent decision the Court decided contrarily. It held that the land reform programme was constitutional and found that there was no breach of the rule of law concerning the actions taken on the farms. In 2005 the amendment to the Zimbabwean Constitution finally formalised the expropriation of the Claimant's farms. Most relevant to the facts of the case is the existence of the Bilateral Investment Treaty between the Netherlands and Zimbabwe ${ }^{10}$, concluded in 1996 (hereinafter BIT). As to the main submissions of the Parties: the Claimants requested the Tribunal to declare Zimbabwe responsible for its unlawful action and to order Zimbabwe to compensate them for all the damages suffered, plus interest and costs. They based their claims on the BIT and alleged that the Zimbabwean government violated the Treaty's provisions on expropriation, on fair and equitable treatment, and on full protection and security. Zimbabwe admitted that the Claimants did not receive any compensation as required by the BIT.

\section{The decision}

In its decision, the Tribunal dealt with three main aspects: firstly, with the alleged breaches of the BIT; secondly, with the evaluation of the damages; and finally with interest and costs.

Article 36 ICSID Convention.

9 Article 38 ICSID Convention.

10

See above, note 2 . 


\section{The obligations under the BIT}

Concerning the first point, the Tribunal considered the question of whether Zimbabwe violated its obligation to pay just compensation under Article 6 of the BIT. Although Zimbabwe had admitted that no compensation was paid, it tried to justify its actions. It raised the defense that a state of necessity or emergency existed which relieved it of its obligations under the BIT. The policy of land redistribution was necessary to rectify the unjust land ownership patterns remaining from colonial times. In this respect it invoked Article 7 of the BIT, as well as Zimbabwean domestic law and customary international law. The Tribunal stated that ultimately international law, not the domestic law of Zimbabwe, would determine whether the Respondent can rely on an emergency defense in the dispute. As the BIT doesn't release Contracting Parties from their obligation to pay just compensation in cases of national emergency, the question had to be answered exclusively under international law. The Tribunal admitted the state of necessity as an argument recognised by customary international law. ${ }^{11}$ However, it can be invoked only under certain strictly defined conditions. According to the Tribunal, Zimbabwe raised the state of necessity only to justify the measures of expropriation. Nonetheless, it had not shown why the alleged state of necessity would have prevented it from paying compensation. As a consequence, the Tribunal concluded that Zimbabwe breached its obligation under Article 6 of the BIT to pay just compensation to the Claimants. Therefore, with regard to the other alleged violations of the BIT, the Tribunal stated that it was not necessary to consider them. Consequently, the sole task left for the Tribunal was to fix the damages due to the Claimants.

\section{The evaluation of the damages}

As to the evaluation of the damages the first question to decide was whether there is a difference between a lawful and an unlawful expropriation. In this respect the Respondent argued that the damages must be calculated as specified in the relevant Article of the BIT (Article $6[\mathrm{c}]$ ). The Claimants objected that the BIT only provided the standard of compensation for lawful expropriation. By contrast, compensation due in case of unlawful expropriation must be calculated according to customary international law. ${ }^{12}$ Although the Tribunal acknowledged the distinction between lawful and unlawful expropriation in international law, it stated that the distinction was only relevant in two cases: ${ }^{13}$ first, when award-

11 According to the jurisprudence of the International Court of Justice in the case Gabčíkovo-Nagymaros (Gabčíkovo-Nagymaros Project [Hungary v. Slovakia], 1997 ICJ 7 [Judgment of Sept. 25]).

12 To underline this argument the Claimants referred to relevant jurisprudence of the Permanent Court of International Justice in the Chorzów Factory case (Case Concerning the Factory at Chorzów [Germany v. Poland] 1928 PCIJ [ser. A] No. 17 [Judgment of Sept. 13]).

13 The Tribunal based this differentiation on a quotation of the decision by the Iran-United States Claims Tribunal in the Phillips Petroleum case (Philipps Petroleum Co. Iran v. Iran, Partial Award, Iran-U.S. Cl. Trib., No. 425-39-2 [June 28, 1989]). 
ing restitution; second, when the value of the property has increased between the date of expropriation and the later date of the decision awarding compensation. The Tribunal found that neither of the two options was an issue here, so that the differentiation between lawful and unlawful expropriation was irrelevant to the case. A further question arose concerning the date of evaluation of the damages and on the method to be applied for such an evaluation. On the first point, the Tribunal determined that the property must be evaluated at the date of dispossession. In this regard, the Tribunal referred to both general international law and the relevant provision of the BIT. As the exact dates of dispossession were in dispute, the Tribunal had to determine the various dates concerning the different farms. The main difficulty in this respect was how to deal with the invasions on the farms by the war veterans and if Zimbabwe could be held responsible for those events. The Tribunal found a way to come up with a solution without answering the latter question. It distinguished between two cases: at first, there was the majority of cases in which the farms were confiscated through expropriation orders under Section 8 of the Land Acquisition Act. Although most of the farmers had previously been forced to abandon their farms due to invasions, the Claimants agreed to fix the date of the evaluation of damages at the date of the relevant governmental orders. That's why, according to the Tribunal it was not necessary to decide on the impact of those invasions. Thus it retained the date of issuance of the expropriation orders as the relevant date. However there was a second group of three cases in which no expropriation orders had been issued. The Tribunal decided that these farms were seized under the Rural Land Occupiers Act of $2001^{14}$ which protected illegal occupiers from eviction. As the war veterans who occupied those three estates in 2001 were "protected occupiers" under the Act (Article 3 [2]), the Claimants were unable to recover the possession of their land. According to the Tribunal, this fell within the responsibility of the Respondent. The relevant date for the evaluation of damages was thus the date of entry into force of the Rural Land Occupiers Act. ${ }^{15}$ After elaborating on the date of evaluation, the Tribunal had then to decide on the method of evaluation. The Tribunal sided with the Claimants that compensation must represent the "genuine value" of the investment, which corresponds to the fair market value. This result could be equally drawn from Article 6 of the BIT or general international law. Further, the Tribunal rejected Zimbabwe's argument that the calculation of the damages should take into account the initial amount of the investment, the date of the investment and its past profits. The Respondent also submitted that discounting from the market value must be made in case of large scale nationalisations. The Tribunal objected that under general international law as well as under the Investment Treaty the value of the investment has to be calculated independently of the origin and past success of the investments, as well as of the number and aim of the expropriations carried out. In the next paragraph the Tribunal elaborated in detail on the evaluation of damages. 
The amounts suggested by Zimbabwe's experts were rejected as obviously too low. The Tribunal also criticised the Claimant's valuation method for not fully considering Zimbabwe's economic situation in the relevant years and arrived at a lower figure of 7.2 Million Euros for all the farms. In a separate calculation the Tribunal also considered the value of the movable assets left on the farms. Finally the Tribunal agreed with the Claimants that they must obtain reparation for the disturbance resulting from the taking over of their farms, for the necessity for them to start a new life in another country and the tangible expenses related to that. It evaluated the damages suffered in this respect for each Claimant at 20000 Euros. Furthermore, in the hearing, the Claimants had requested for the first time moral damages, additionally and distinct from the disturbance claim, evaluated at 100000 Euro for each Claimant. The Court stated that those claims were inadmissible because of the very late stage of the submission. However, it mentioned that the moral damages claim would partially overlap with the damages already compensated by the disturbance indemnity. The Tribunal ordered the Respondent to pay the compensation within a period of three months.

\section{Interest and costs}

In its final section, the Tribunal dealt with interest and costs. With respect to interest, the Tribunal granted a $10 \%$ rate compounded bi-annually. Regarding costs, the Tribunal referred firstly to the general practice in international arbitration that the successful party under an award should recover its legal costs. However, the Tribunal decided differently, taking into account the situation in Zimbabwe in 2001 and 2002. Thus, the Tribunal exercised its discretion ${ }^{16}$ that the costs for representation before the Tribunal will remain with the Parties. Only the costs for the Tribunal and ICSID were imposed on the Respondent.

\section{Subsequent events}

\section{Enforcement}

After presenting the decision, the crucial questions remaining are: what has happened subsequently and did Zimbabwe finally pay the amounts due to the farmers? The deflating answer is that to date, the Claimants have not been successful in obtaining any payment from the Republic of Zimbabwe and corresponding attempts to pursue diplomatic channels through the Dutch Embassy in Harare failed. ${ }^{17}$ Thus, to realise the Claimant's rights under the award, an aspect of the ICSID Convention becomes important: an ICSID award is binding and enforceable in each Contracting State as if it was a final judgment of a national 
court in that State. ${ }^{18}$ In particular, it means that Zimbabwean assets can be seized in any of the Contracting States to the ICSID Convention of which there are more than 140. Thus, immediately after the award was rendered the Claimants announced that if Zimbabwe didn't pay they would start enforcement proceedings. ${ }^{19}$ However, the crucial impediment that the Claimants face in attempting to enforce the award in jurisdictions outside of Zimbabwe is related to the identification of property belonging to the cash-strapped government. ${ }^{20}$ Subsequently, to set an example, the Claimants finally filed a Petition to confirm the arbitration award with a United States District Court on the $24^{\text {th }}$ September $2009 .^{21}$ Zimbabwe for its part failed to respond to the Petition. On February $1^{\text {st }}$, a judgment was rendered in favour of the Petitioners. Using the Euro/U.S. Dollar exchange rate on the day of the judgment, the Petitioners were awarded 11,5 Million U.S. Dollars for the damages. Additionally, the Court granted the amount of 13,5 Million U.S. Dollars for interest, due as of the day of the judgment, plus 232500 U.S. Dollars for the ICSID fees. In contrast to the decision of the ICSID Tribunal, the Court awarded attorney's fees and costs associated with this proceeding to the Petitioners. Thus the total of the judgment amounted to over 25 Million U.S. Dollars. With every day of non payment, the interest continues to accrue in the future pursuant to the arbitration award and as expressly confirmed by the District Court. Hence the judgment can be considered as a further success for the farmers on the way to realising their rights.

\section{Upcoming claims}

Another interesting point is the significance of the decision to other foreign nationals who also lost their farms in Zimbabwe. In this respect the case was meant to be a test case. ${ }^{22}$ Following the decision, one of the counsel for the Claimants announced that his law firm

Article 53, 54 ICSID Convention.

19 Peta Thornycroft, Zimbabwean assets face seizure after tribunal rules for farmers, Telegraph, 27.04.2009, http://www.telegraph.co.uk/news/worldnews/africaandindianocean/zimbabwe/ 5232452/Zimbabwe-assets-face-seizure-after-tribunal-rules-for-farmers.html (all references to a webpage are checked on 28.05.2010).

The English "Telegraph" suggested for example that passenger jets of Air Zimbabwe which land at London's Gatwick airport could be confiscated: note 19.

Funnekotter et al v. Republic of Zimbabwe, New York Southern District Court, Case No. 1:09-cv8168-CM, Petition to confirm arbitration, filed Sept. 24, 2009. The petition was based on 22 U.S.C. $\$ 1650$ a. In approaching specifically this Court, the Petitioners could follow the example of a case which was brought before the same Court earlier in the year also with the request to confirm an ICSID award (see page p. 2 of the Petition).

Luke Eric Peterson, An update on moral damages in investment treaty arbitration, Kluwer Arbitration Blog, 07.05.2009, http://kluwerarbitrationblog.com/blog/2009/05/07/an-update-on-moraldamages-in-investment-treaty-arbitration/. 
was in the process of organising additional claims for some 50 European nationals. ${ }^{23} \mathrm{Zim}$ babwe concluded Bilateral Investment Treaties with several countries in Europe, like Germany, France and Sweden. ${ }^{24}$ An interesting issue in an upcoming claim will be the question of whether moral damages can be requested, as this matter was left open in the present case due to the late submission. ${ }^{25}$

\section{E. In comparison: the judgment of the SADC Tribunal}

\section{The judgment}

As already mentioned in the introductory section, the present case has to be seen in the context of the earlier judgment by the SADC Tribunal in the Campbell-case. In this first judgment by the newly established regional Tribunal, ${ }^{26}$ it took the opportunity to establish itself as a forum providing relief for human rights violations. Primarily set up to resolve disputes arising from closer economic and political union within the community, ${ }^{27}$ the court established that the principles and objectives of the SADC Treaty - which comprise the respect for human rights, democracy and the rule of law (Article 4) - are not just vague declarations but that the Member States are bound by them and they are reviewable by the Tribunal. Thereby, it provided for an avenue of redress for farmers of many different nationalities ${ }^{28}$ who suffered human rights violations during the Zimbabwean land reform programme. In its judgment the Tribunal held that the Republic of Zimbabwe was in breach of its obligations under Article 4 of the SADC Treaty. According to the Tribunal, the Respondent had violated essential elements of the rule of law in denying access to court to the Applicants. Additionally, the land reform programme was found to be racially discriminatory and thus in breach of the obligations under Article 6 of the SADC Treaty, which comprises a non-discrimination clause. Finally the Respondent had violated international law by refusing the payment of compensation. Therefore, the court ordered the Respondent firstly, to take all necessary measures to protect the ownership of the lands of the Applicants and secondly, to pay fair compensation on or before the $30^{\text {th }}$ June 2009 to the Applicants that have already been evicted from their lands.

Damon Vis-Dunbar, Tribunal orders compensation in Dutch farmers' claims against Zimbabwe, Investment Treaty News, 28.04.2009, http://www.investmenttreatynews.org/cms/news/archive/ 2009/04/28/tribunal-orders-compensation-in-dutch-farmers-claims-against-zimbabwe.aspx .

Visit the UNCTAD homepage: http://www.unctadxi.org/templates/DocSearch 779.aspx .

See above, at C II 2; note 22.

The establishment of the Tribunal was already laid down in Article 9 and 16 of the SADC Treaty but it took 14 years before the Tribunal began its work in 2007.

Frans Viljoen, International Human Rights Law in Africa, Oxford 2007, p. 503.

As laid down in Article 15 (1) of the SADC Protocol on Tribunal (note 29), the jurisdiction of the Tribunal encompasses "disputes between States, and between natural or legal persons and States" without differentiating on the nationality. 


\section{The enforcement side}

According to Article 16 (5) of the SADC Treaty and Article 24 (3) of the Protocol on Tribunal $^{29}$, the decisions of the Tribunal are final and binding. However, immediately after the decision, the Zimbabwean government declared that, despite the judgment, it was not willing to stop its land reform programme. ${ }^{30}$ One month after the judgment, Mr. Campbell filed an urgent application to register the Tribunal's judgment in the Zimbabwean High Court to give it effect in Zimbabwean national law - which was rejected. ${ }^{31}$ By contrast to ICSID awards which immediately have the same status as judgments by a national court, ${ }^{32}$ the enforcement of judgments by the SADC Tribunal is governed by the national law for the registration and enforcement of foreign judgments. ${ }^{33}$ In the following months the violent invasions on farms continued. In March 2009 it was reported that the violations even increased with special focus on farmers that were amongst the Applicants in the process before the Tribunal. ${ }^{34}$ In May 2009 Mr. Campbell and one other farmer filed an urgent application before the Tribunal, seeking a declaration that the Respondent is in breach and contempt of the Tribunal's judgment. ${ }^{35}$ On the $5^{\text {th }}$ June 2009 the Tribunal agreed that the Republic of Zimbabwe failed to comply with the judgment of the Tribunal. ${ }^{36}$ As a consequence it referred the issue to the SADC Summit ${ }^{37}$ for the latter to take appropriate action pursuant to Article 32 (5) of the SADC Protocol on Tribunal. ${ }^{38}$ Despite this judicial progress, the homestead of Mr. Campbell was finally destroyed by fire at the end of August

SADC Protocol on Tribunal and Rules of Procedure thereof, 07.08.2000 (adopted), 14.08.2001 (entered into force), amended by Agreement amending the Protocol on Tribunal, 30.10.2002 (adopted).

Doro Grebe, Mugabe-Regierung akzeptiert Urteil nicht, Allgemeine Zeitung, 02.12.2008, http:// www.az.com.na/afrika/mugabe-regierung-akzeptiert-urteil-nicht.77410.php .

Alex Bell, Outrage as High Court dismisses SADC Land Ruling, 27.01.2010, http://www. zimbabwemetro.com/headline/outrage-as-high-court-dismisses-sadc-land-ruling/ .

See above, at D I.

Article 32 (1) SADC Protocol on Tribunal.

Doro Grebe, "Das schlimmste Wochenende meines Lebens", Allgemeine Zeitung, 17.03.2009, http://www.az.com.na/afrika/simbabwe.65972.php .

According to Article 32 (4) of the SADC Protocol on Tribunal, may any failure by a State to comply with a decision of the Tribunal be referred to the Tribunal by any party concerned.

The Summit of Heads of State and Government is the highest decision-making body within SADC (Article 9 [1], 10 SADC Treaty).

38 According to Article 32 (5), the Tribunal can report the State's failure to the Summit of Heads of State and Government for the latter to take appropriate action. Subsequently, according to Article 33 of the SADC Treaty, the Summit may impose sanctions for non-compliance on a case-by-case basis. 
2009. ${ }^{39}$ Also in August, the Zimbabwean government took a new position concerning the SADC Tribunal. The country's Justice Minister wrote a letter to the Tribunal whereby the Zimbabwean government withdrew recognition of the Tribunal's authority. ${ }^{40} \mathrm{He}$ argued that the Tribunal was illegal as long as the Protocol on Tribunal was not ratified by at least two-thirds of SADC Member States. What the Justice Minister did not mention was that, in 2001, the SADC Treaty was amended and the SADC Tribunal established as an integral organ of SADC. As a result of this amendment the Articles of the Protocol on Tribunal which had required the two-thirds ratification were repealed. As a consequence, there were high expectations of the SADC Summit which met in Kinshasa in September 2009. ${ }^{41}$ However, despite the referral of the issue to the Summit by the Tribunal, the Summit completely failed to deal with Zimbabwe's contempt of court and did not address the issue at all. In fact, its final Communiqué called on the international community to lift sanctions against Mugabe and his regime and emphasised the progress that had been made in the country in the political field. ${ }^{42}$ Whilst this was celebrated in Zimbabwe's state media as a triumph for Mugabe, it was sharply criticised by opposition parties and human rights activist groups all over Southern Africa. ${ }^{43}$ No further action in respect of the enforcement of the judgment has been undertaken so far by SADC. Meanwhile the farmers had initiated several further attempts to register the SADC Tribunal's judgment before the High Court in Zimbabwe but without success. Finally, in a decision in January 2010, the High Court rejected the registration, accusing the judgment of contravening Zimbabwe's Constitution and public policy. ${ }^{44}$ The Court stated that it recognised that Zimbabwe is bound in general by the judgment under international law, but noted that in this case the "greater public good" of the agrarian reform must prevail. ${ }^{45}$ As a consequence, Zimbabwe's Commercial Farmers'

Doro Grebe, Bomben auf Mount Carmel explodiert, Allgemeine Zeitung, 14.09.2009, http:// www.az.com.na/afrika/bomben-auf-mount-carmel-explodiert.93061.php .

Zimbabwe pulls out of SADC Tribunal, People's Daily Online, 02.09.2009, http://english. peopledaily.com.cn/90001/90777/90855/6746705.html .

Peta Thornycroft, Upcoming SADC Summit Strains Zimbabwe Inclusive Government, 03.09.20009, http://www1.voanews.com/english/news/a-13-2009-09-03-voa34-68807117.html . Communiqué of the $29^{\text {th }}$ Summit of Heads of State and Government of the SADC, held in Kinshasa from Sept. 8-9, 2009.

Tichaona Sibanda, Zimbabwe: SADC want "sanctions" against Mugabe and cronies lifted, 09.09.2009, http://allafrica.com/stories/200909090882.html .

Gramara (Pvt) Ltd and Another v. The Republic of Zimbabwe et al, HH 169-2009, HC 33/09, Xref. HC 5483/09 (Jan. 26, 2010); see the statement on the judgment and a summary of the latter by SADC Tribunal Rights Watch: http://www.swradioafrica.com/pages/sadctribunal250110.htm\# summary; Fidelis Munyoro, Zimbabwe: High Court rejects land ruling, 27.01.2010, http:// allafrica.com/stories/201001270021.html . 
Union decided once again to approach the SADC Tribunal on this issue. ${ }^{46}$ Finally, a new application by the Commercial Farmers' Unions of Zimbabwe and South Africa was sent to the SADC Tribunal on the $12^{\text {th }}$ February 2010. It is again (like the application of May 2009) an urgent application, seeking a declaration that Zimbabwe is in continued breach and contempt of the Tribunal's judgment of 2008. ${ }^{47}$ The Applicants expect the Tribunal to refer the issue once more to the SADC Summit which will be held in August this year in Windhoek under Namibian Chairmanship and they hope that the Summit this time might consider sanctions against Zimbabwe or even decide to suspend it from SADC. ${ }^{48}$ More recently, a major success concerning enforcement resulted through a confirmation of the SADC judgment by the South African judiciary. The North Gauteng High Court in Pretoria had ordered in November 2009, that the judgment has to be respected by the South African government. A further case was filed on $12^{\text {th }}$ January with the same Court in order to seize Zimbabwean assets hold in South Africa. Subsequently, the Gauteng Court came up with a land mark decision in February $2010^{49}$ and ordered that the SADC Tribunal rulings ${ }^{50}$ in the Campbell-case are declared to be registered, recognised and enforceable by the High Court of South Africa pursuant to Article 32 of the SADC Protocol on Tribunal. As a result, ownership documents of a Cape Town house belonging to the Zimbabwean government have already been handed over. 51

\section{F. Conclusion}

Firstly, the ICSID award covers some interesting issues concerning investment law, especially with respect to the details of the calculation of damages. Furthermore, it is remarkable to observe the influence of investment law on the conditions of land reform programmes, which are relevant to most states with a colonial history; this influence exists at least in so far as foreign nationals are concerned. However, by far the most significant is the fact that the case involves human rights violations and deals with actions of a state

46

47

48

49

Fick and Others v. Government of the Republic of Zimbabwe, Case No. 77881/2009, (Febr. 25, 2010).

50 The judgment of $28^{\text {th }}$ of November 2008 and the ruling of $5^{\text {th }}$ June 2009.

51 Nyasha Nyaungwa, Zimbabwean government could lose more assets in SADC, Namibia Economist, 23. 04.2010, http://www.economist.com.na/index.php?option=com_content\&view= article \&id=21423:zimbabwean-government-could-lose-more-assets-in-sadc\&catid=576:speakyour-mind $\&$ Itemid=61 . 
which is not based on the rule of law. Here, the international courts fill the gap which is left at national level: as no independent judiciary existed anymore in Zimbabwe the farmers could not expect protection before the national courts. Therefore they attempted to seek redress before different international Tribunals like the SADC Tribunal and ICSID, both not intended to consider human rights issues originally. In this respect the two decisions provide interesting grounds for comparison of how the two Tribunals handle the human rights topic. Whilst the SADC Tribunal refers to human rights standards and the rule of law as laid down in the SADC Treaty, the ICSID Tribunal deals with the case under investment law without expressly referring to human rights. Additionally, it is noteworthy to evaluate the enforcement mechanisms of the two different legal regimes and their effectiveness in influencing a state such as Zimbabwe. The SADC Tribunal for its part has failed on the enforcement side since Zimbabwe has completely ignored the judgment and there is a lack of political will amongst SADC members to impose pressure upon Zimbabwe. However, as the decisions by the South African High Court show the issue is ongoing. Further the new attempt by Zimbabwean farmers to approach the SADC Tribunal may bring progress, and it will be interesting to observe the discussions at the upcoming SADC Summit later in the year.

By contrast, independently of the actual outcome in practice, ICSID provides a much more effective regime as the award has the same status as a judgment by a national court of a Contracting State. Therefore it cannot be so easily ignored by the Zimbabwean government. That might be a reason why Zimbabwe co-operated from the very beginning much better with the ICSID Tribunal than with the SADC one. Here it will be interesting to see how successful the Claimants will be in finding and seizing Zimbabwean assets and if the awaited claim by Zimbabwean farmers of other nationalities can contribute to raising pressure on the Zimbabwean government concerning human rights violations through the land reform programme.

However, in Zimbabwe forced land takeovers are continuing to date, including land meant to be protected under Bilateral Investment Treaties. ${ }^{52}$ Thus unfortunately, the ICSID award has so far had no general impact on the situation in the country. 